J. LIQ. CHROM. \& REL. TECHNOL., 19(16), 2615-2621 (1996)

\title{
DETERMINATION OF ORGANIC ACIDS IN APPLE JUICE BY CAPILLARY LIQUID CHROMATOGRAPHY
}

\author{
D. Blanco, ${ }^{1}$ M. E. Quintanilla, \\ J. J. Mangas, ${ }^{2}$ M. D. Gutierrez ${ }^{1}$ \\ ${ }^{1}$ Departamento de Química Física y Analítica \\ Universidad de Oviedo \\ 33006 Oviedo, Spain \\ ${ }^{2}$ Centro de Investigación Aplicada \\ y Tecnología Agroalimentaria \\ 333000 Villaviciosa \\ Asturias, Spain
}

\begin{abstract}
The organic acids quinic, malic, shikimic and citric were separated on a packed reverse phase fused-silica capillary column using $0.01 \mathrm{M} \mathrm{K}_{2} \mathrm{HPO}_{4} / \mathrm{H}_{3} \mathrm{PO}_{4}$ at $\mathrm{pH} 2.7$ as eluent at a flow rate of 2 $\mu \mathrm{L} / \mathrm{min}$, and determined with UV detection. Conventional liquid chromatographic equipment was adapted for such purposes.

The organic acids were able to be separated with detection limits of $2.4,2.1,0.04$ and $2.9 \mathrm{ng}$, respectively. Application of the proposed method to the quantification of organic acids in apple juice is reported.
\end{abstract}




\section{INTRODUCTION}

Carboxylic acids are one of the most frequently assayed types of substances among those found in fruits on account of the significant role they play in maintaining quality and nutritional value. In fact, they have a direct influence on the sensory properties of fruits and their juices, and could be added to juices to prevent sedimentation or darkening, or even to flavour them. At the same time, some organic acids are regarded as indicators of ripeness, bacterial activity, or may be used to reveal potential adulteration.

In this study, from among the different analytical techniques available (titrimetric, photometric, enzymatic, electroanalytic and chromatographic) for the determination of organic acids in foods, high performance liquid chromatography was preferred, due to its rapidity, sensitivity and specificity and, since this method entails uncomplicated sample pre-treatment. As in gas chromatography, the actual trend in liquid chromatographic is to reduce the internal diameter of the chromatographic columns to below $1 \mathrm{~mm}$. The most important advantages of microcolumn separations may be summarised as: increased mass sensitivity, higher separation efficiency, improved speed of analysis, less sample volume, and less solvent consumption. ${ }^{2-4}$ The purpose of this work was to separate and determinate the principal organic acids in apple juice by capillary liquid chromatography(CLC).

\section{EXPERIMENTAL}

\section{Reagents}

Analytical standard-grade quinic, malic, shikimic and citric acids were obtained from Sigma (St Louis, MO, USA), and were used without further purification. High purity water was obtained through a Millipore Milli-Q system (Milford, MA, USA). The mobile phases used were buffered solutions containing $\mathrm{K}_{2} \mathrm{HPO}_{4}$ and adjusted to different $\mathrm{pH}$ values with $\mathrm{H}_{3} \mathrm{PO}_{4}$. All solutions used were filtered across a $0.22 \mu \mathrm{m}$ Millex membrane to remove any impurities.

\section{Apparatus and Conditions}

The micro-LC equipment consisted of a Kontron 422 pump (Kontron Instruments, Milan, Italy) connected to a T-flow-split system wich enabled the mobile phase $(0.05 \mathrm{~mL} / \mathrm{min})$ to be distributed between the by-pass and the microLC column $(2 \mu \mathrm{L} / \mathrm{min})$ connected to a zero-dead volume Valco injector equipped with a $60 \mathrm{~nL}$ internal loop (Valco, Houston, TX, USA). Detection was performed by means of Kontron model $430 \mathrm{UV}-\mathrm{V}$ is detector with a $90 \mathrm{~nL}, 20 \mathrm{~mm}$, flow cell. 
Column effluents were monitored at $206 \mathrm{~nm}$ and were recorded and integrated with a Data System 450 software from Kontron Instruments. Analyses were carried out in the isocratic mode by using $0.01 \mathrm{M} \mathrm{K} \mathrm{HPO}_{4} / \mathrm{H}_{3} \mathrm{PO}_{4}$ at $\mathrm{pH} 2.7$ as eluent at room temperature $\left(20 \pm 2{ }^{\circ} \mathrm{C}\right)$. The microcolumn used was a Spherisorb ODS-2 ( $300 \times 0.32 \mathrm{~mm}$ i.d., $5 \mu \mathrm{m}$ ) (LC Packings, Amsterdam, The Netherlands).

\section{Apple Juice Samples}

The apples were harvested close to optimal processing maturity, and the juice was produced without cold storage previous to sampling. Single-variety juices were extracted from typical varieties employed for apple juice manufacture. Two different technological treatments were employed in order to stabilise the apple juice obtained: ceramic (Gamma Alumina) crossflow microfiltration(MF) with 0.2 $\mu \mathrm{m}$ pore size (Millipore, Milford, MA, USA), and ultrafiltration(UF) by means of a zirconium oxide membrane with 50K of MWCO (TECHSEP Carbosep, Lyon, France). The filtration conditions were as follows: superficial velocity $5 \mathrm{~m} / \mathrm{s}$, pressure $3.5 \mathrm{bar}$, temperature $30^{\circ} \mathrm{C}$ for $\mathrm{MF}$ and $30^{\circ} \mathrm{C}$ and $50{ }^{\circ} \mathrm{C}$ for UF. The juices were frozen $\left(-20{ }^{\circ} \mathrm{C}\right)$ until their analytical determination and chromatographicanalysis was carried out by direct injection of the sample.

\section{RESULTS AND DISCUSSION}

We studied the effect of the elution conditions $(\mathrm{pH}$, ionic strength, organic modifier and flow-rate) on the resolution of the acids concerned, by varying one parameter at a time, while keeping all the others constant. Taking into account the pKs of the different organic acids assayed, the previous studies carried out by our group, ${ }^{5-7}$ and the minimum $\mathrm{pH}$ recommended for the capillary chromatographic column operation, we assayed the $\mathrm{pH}$ ranging between 2.5 and 2.9. For $\mathrm{pHs}$ close to 2.9 a good resolution does not exist among the malic and shikimic acids, whereas for low pHs, the elution time of the citric acid is too high. In consequence, a pH of 2.7 was selected. The effect of the ionic strength of the eluent on the retention time of carboxylic acids seems to be slight, but it can be observed, that when the ionic strength decreases (below $10^{-3} \mathrm{M}$ ), the width of the peaks increases and the chromatograms lose resolution. In consequence, an ionic strength of $10^{-2} \mathrm{M}$ was fixed. Taking into account the low lipophility of carboxylic acids, the acetonitrile organic modifier percentages were varied between $0.25 \%$ and $0.75 \%$. In fact, an improvement in the performance in presence of the organic modifier is not observed. On the contrary, starting from $0.5 \%$ of organic modifier, the shikimic and malic acids are partly overlapped. The flow rate, selected on the basis of the resolution, time of analysis and pressure drop across column, was 2 $\mu \mathrm{L} / \mathrm{min}$. Figure 1 shows the chromatogram obtained under these optimised conditions. 


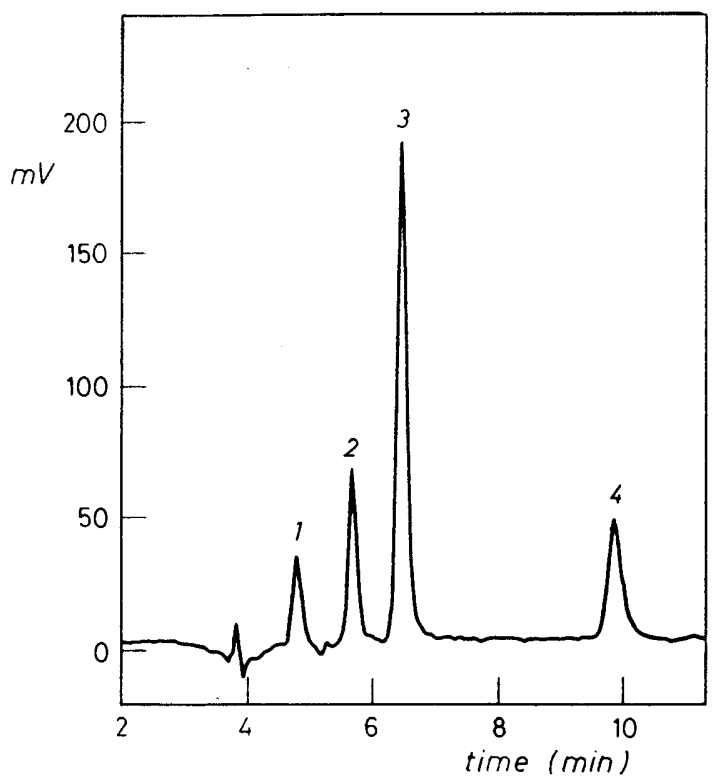

Figure 1. Chromatogram of a standard organic acid mixture. Column: Spherisorb ODS-2, $300 \times 0.32 \mathrm{~mm}$ i.d., $5 \mu \mathrm{m}$. Mobile phase: $\mathrm{K}_{2} \mathrm{HPO}_{4} / \mathrm{H}_{3} \mathrm{PO}_{4} 0.01 \mathrm{M} ; \mathrm{pH} 2.7$; flow rate 2 $\mu \mathrm{L} / \mathrm{min} .1=$ quinic acid; $2=$ malic acid; $3=$ shikimic acid; $4=$ citric acid.

The quantification of the organic acids was achieved by using the external standard method. Calibration plots were generated by repeated injections of $60 \mathrm{~nL}$ of standard solutions of organic acids of different concentrations, and the resulting plots were stored in the data module. A good correlation of the standards and corresponding peak areas $(r=0.999)$ over the range between the detection limits and $120 \mathrm{ng}$ for quinic and citric acids, $600 \mathrm{ng}$ for malic acid and $6 \mathrm{ng}$ for shikimic acid, were established. A volume of $60 \mathrm{~nL}$ of the apple juice was then injected and the amount of organic acids was obtained directly from the data module. The data module calibration was checked regularly with standard solutions.

Recovery studies were performed for an apple juice. Each organic acid was spiked at three different concentrations in triplicate on different days. Typical recoveries ranging from $91-105 \%$ for organic acids at all spiking levels were obtained. The coefficients of variation were generally less than $5 \%$. These results indicate that the method has an adequate degree of accuracy for the analysis of these solutes. The limits of detection for the described method were 2.4, 2.1, 0.04 and $2.9 \mathrm{ng}$ per injection (signal-to-noiseratio $=3$ ) for quinic, malic, shikimic and citric acids, respectively. 


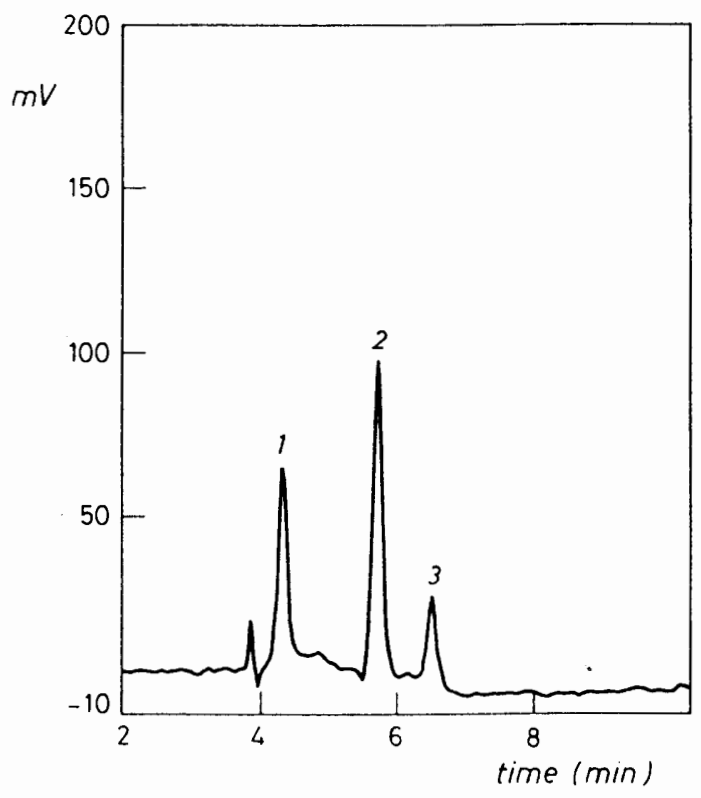

Figure 2. Typical chromatogram of organic acids in apple juice. Column and Chromatographicconditions as in Figure $1.1=$ fructose; $2=$ malic acid; $3=$ shikimic acid.

A typical chromatogram for an apple juice obtained according to the technologies described above and using the operating conditions specified, is shown in Figure 2. As can be seen, only malic and shikimic acids are present in these apple juices. We could not determine the presence of citric acid as it was found in small concentrations and was only detected when malic acid occurred at greater concentrations, thereby confirming that changes in both acids follow a similar pattern. ${ }^{6}$

As has been reported, ${ }^{8}$ the quinic acid content decreases during the ripening of the fruit. This decrease may be the result of the synthesis of chlorogenic acid. As these juices were obtained from ripe apples, their concentrations were below , the detection limits of the method.

Table 1 shows the changes in malic and shikimic acids when the apple juice was clarified by membrane technology. As can be seen, the contents of organic acids in the apple juices processed decrease with the technological treatment employed in their stabilisation. This fact has also been reported in the clarification of other products such as wine and grape juice by microfiltration and ultrafiltration. ${ }^{9-11}$ 


\section{Table 1}

Variation of Organic Acid Contents (mg/L) in Apple Juice According to the Type of Membrane Used for its Stabilization.

\begin{tabular}{ccccc} 
Acid & $\begin{array}{c}\text { Amount in } \\
\text { Raw Apple } \\
\text { Juice }\end{array}$ & $\begin{array}{c}\text { Amount in } \\
\text { MC Apple } \\
\text { Juice }\end{array}$ & $\begin{array}{c}\text { Amount in } \\
\text { UC }\left(3^{\circ} \text { C) }\right. \\
\text { Apple Juice }\end{array}$ & $\begin{array}{c}\text { Amount in } \\
\text { UC (50 }{ }^{\circ} \text { C) }\end{array}$ \\
$\begin{array}{c}\text { Malic } \\
\text { Apple Juice }\end{array}$ \\
Shikimic & 7108.6 & 4421.8 & & - \\
Malic & 14.7 & 5.7 & & \\
Shikimic & 5446.3 & & 3318.9 & 4155.3 \\
& 23.2 & & 13.0 & 17.4 \\
\hline MC, microfiltrate; UC, ultrafiltrate & & &
\end{tabular}

The temperature effect could have a very important influence on the recovery level of the organic acids during membrane treatment. The higher recovery of malic and shikimic acids was monitored in UF at higher temperatures, wich could be explained on the basis of a greater solubilizing effect.

\section{CONCLUSIONS}

Reverse phase HPLC with microcolumns provides a rapid, simple and economic alternative for the separation and determination of organic acids. The proposed method is particularly suitable for determining quinic, malic, shikimic and citric acids in apple juice, but it can also be applied to other sample types.

\section{ACKNOWLEDGEMENTS}

This work was supported financially by the Comisión Interministerial de Ciencia y Tecnología (Project AL192-1027-C03)

\section{REFERENCES}

1. D. Blanco Gomis, "HPLC Analysis of Organic Acids", in Food Analysis by HPLC, L.M.L. Nollet, ed., Marcel Dekker, Inc., New York, 1992, pp. 371 385.

2. M. V. Novotny, D. Ishii, Microcolumn Separations, Elsevier, 1985. 
3. J. W. Jorgenson, J. de Wit, "Detection in Microcolumn Liquid Chromatography," in Detectors for Capillary Chromatography, H.H. Hill, D.G. McMinn, eds., John Wiley \& Sons, New York, 1992, pp. 395-421.

4. J. P. Chervet, R. E. J. van Soest, J. P. Salzmann, LC-GC, 5, 33-38 (1992).

5. D. Blanco, M. J. Morán, M. D. Gutiérrez, A. Sanz-Medel, Chromatographia, 24, 347-350(1987).

6. D. Blanco, M. J. Morán, M. D. Gutiérrez, J. J. Mangas, Chromatographia,25, 1054-1058(1988).

7. D. Blanco, M. J. Morán, M. D. Gutiérrez, J. J. Mangas, J. Liq. Chromatogr., 14, 2707-2719(1991).

8. D. Blanco, M. J. Morán, M. D. Gutiérrez, J. Moreno, E. Dapena, J. J. Mangas, Z. Lebensm. Unters Forsch., 194, 33-37 (1992).

9. M. Serrano, S. B. Sachs, P. Ribereau-Gayon, Conn. Vigne Vin, 18, 135-154 (1984).

10. C. Peri, Bull. O.I.V., 60, 789-800 (1987).

11. C. A. Sims, R. P. Bates, R. P. Johnson, Am. J. Enol. Vitic., 39, 11-17 (1988).

Received March 1, 1996

Accepted March 19, 1996

Manuscript 4102 